\title{
QUANTIFYING THE STOCK OF SOIL ORGANIC CARBON USING MULTIPLE REGRESSION MODEL IN A FALLOW VEGETATION, SOUTHERN NIGERIA OFFIONG, R. A. ${ }^{1}$ and ${ }^{*}$ IWARA, A. I. ${ }^{2}$ \\ DOI: http://dx.doi.org/10.4314/ejesm.v5i2.7
}

Received 28 ${ }^{\text {th }}$ December 2011; accepted 15 ${ }^{\text {th }}$ March 2012

\begin{abstract}
Identifying ecological variables that explain significant variation in the stock of carbon is indeed one way of sustaining its concentration in the soil. The stepwise multiple regression model was employed to identify ecological variables that explained significant variation of carbon in fallow soils. Using fallow genealogical cycles of $1^{\text {st }}, 2^{\text {nd }}, 3^{\text {rd }}, 4^{\text {th }}$ and $5^{\text {th }}$ generations, soil and vegetation variables from 30 sampling plots were collected and subjected to linear regression analysis. The analysis generated three predictive models. The first and second models significantly $(p<0.01)$ explained $78 \%\left(R^{2}=0.78\right)$ and $87 \%\left(R^{2}=0.87\right)$ of the variability in soil organic carbon (SOC), while the third (full) model significantly $(p<0.01)$ explained $89 \%$ in the variability of carbon stock $\left(R^{2}=0.89\right)$ with vegetation cover, available phosphorus and total nitrogen being the most significant predictor variables. The full model was upheld because it identified three significant ecological variables that explained increased variability in the stock of SOC. The study suggested that management of the ecological variables identified in the full model which indeed were associated with the abundance of woody and herbaceous vegetation would not only increase the stock of SOC in the soil, but reduced its concentration in the atmosphere. For this to be feasible mostly in the present changing climate, healthy forest and land management practices, such as the creation of vegetal buffer zones around farmlands, zero-tillage practice, mulching, retaining of forest slash and crop residues, fertilizer application, elongation of fallow periods, and tree planting initiatives in degraded ecosystems were encouraged.
\end{abstract}

Keywords: Stepwise Regression, SOC, Healthy Forest and Management Practices Fallow Genealogy, Woody Perennial Tree Species, Fallow Elongation

\section{Introduction}

It is globally recognized that forest vegetation and soils are principal reservoirs of carbon, as they help to reduce the atmospheric consequences of carbon dioxide $\left(\mathrm{CO}_{2}\right)$ concentration which results in global temperature rise. As a result of their high organic matter status, forest soils are one of the major sequesters of carbon on earth (Dixon et al., 1994). According to Watson et al., (2000), carbon sequestration is the removal of $\mathrm{CO}_{2}$ from the atmosphere (source) into green plants (sink) where it can be stored indefinitely. These sinks can either be above ground biomass (trees) or living biomass below the ground in soil (roots and micro organisms) or in the deeper sub-surface environments. Sequestration, which is relatively a new term, is therefore the storage of all forms of carbon, including storage in terrestrial, geological and aquatic ecosystem (Jina et al., 2008).

Carbon sequestration helps to enhance the storage ability of all potential sinks especially forest ecosystems (soil and vegetation) as well as expand the number and type of sinks in which carbon storage is possible. The practice of understanding and enhancing the natural processes that remove $\mathrm{CO}_{2}$ from the atmosphere is believed to be one of the most useful methods of mitigating the atmospheric effects of $\mathrm{CO}_{2}$ concentration. Depending on the changes in the level of soil organic matter, soils can act as sinks of carbon concentration in the atmosphere, thereby increasing the concentration of carbon in the soil (Dey, 2005). Therefore, soils according to Lal, (2005) are the largest carbon reservoir of the terrestrial carbon cycle, this is because about three times more carbon is contained in soils than in the world's vegetation; in addition, soils hold double the amount of carbon that is present in the atmosphere (Sheikh et al. 2009). On this regards, Batjes (1999) noted that worldwide, the first $30 \mathrm{~cm}$ of soil holds 1500 petagrams of carbon (Pg carbon).

${ }^{1}$ Dept. of Geography \& Regional Planning, University of

*Corresponding author email:iwaradream2008@yahoo.com 
More so, Lal (2005) reported that forest ecosystems covering about 4.1 billion hectares globally are a major reserve of terrestrial carbon stock. This is because forest vegetation and soil contain about $1240 \mathrm{Pg}$ of carbon (C), and the C stock varies widely among latitudes. However, the concentration of $\mathrm{C}$ in the soil is depleted when vegetation is destroyed through natural (wind, drought, insects and diseases) and numerous anthropogenic activities (logging, fuelwood gathering, deforestation, land preparation for agricultural production, afforestation, plantation management) (Elliot, 2003; Thornley and Cannel, 2000). Elliot (2003) noted that natural disturbance such as fire results in tremendous change in canopy cover, thereby making the area affected susceptible to soil erosion; this affects soil organic carbon (SOC) stock of the surface layer. In addition, severe natural disturbance decreases $\mathrm{C}$ stock as it is characterized by changes in soil moisture and temperature regimes, and succession of forest species with differences in quantity and quality of biomass returned to the soil. Nevertheless, management systems that maintain a continuous canopy cover and mimic regular natural forest disturbance according to Thornley and Cannell (2000) are likely to achieve the best combination of high wood yield and C storage. In the same way, Hoover, (2003) noted that harvesting and site preparation, soil drainage and planting of adapted species with high NPP and more below-ground biomass production, fertilization and liming are some of the management activities that may impact the SOC stock.

Thus, understanding the factors that affect the stocks of carbon in the soil is one of the most important short-term sinks for atmospheric carbon dioxide $\left(\mathrm{CO}_{2}\right)$ fluxes on earth, and an avenue to increase the amount of carbon in the soil. Though, $\mathrm{C}$ exists as an inseparable component of vegetation, litter and soil organic matter, and it is primarily lost as an invisible gas (Woomer, 2006). Carbon therefore looks intangible for approximation, yet its concentration can be measured through the identification of vegetation and soil variables (Chave et al., 2005). This perhaps according to Attua (2009) can be obtained through direct field-plot assessment of biomass either through destructive or non-destructive sampling; this approach is believed by scholars to be the most accurate because it is based on direct field sampling. A variety of factors has been identified in the literature to affect the stock or proportion of soil organic carbon (SOC); these include climate, precipitation and temperature (Post et al., 1982; Lal, 2005), soil and landscape such as cation exchange capacity, total nitrogen, clay, available phosphorus (Chandler, 1939; Wilcox et al., 2002; Attua, 2009), topography and aspect such as slope angles and elevation (Prichard et al., 2000), anthropogenic and natural forces (Larionova et al., 2002; Lal, 2005) as well as vegetation characteristics like $\mathrm{DBH}$, tree height, leaf area index, stem density/volume and aboveground biomass (Lal, 2005; Attua, 2009; Woomer, 2006). However, available studies on SOC tend to focus more attention on the estimation of carbon stocks in forest ecosystems using allometric regression models (Hairiah et al., 2001; Lu et al., 2002; Lal, 2005; Chave et al., 2005; Woomer, 2006; Chaidez, 2009), many others focused on the effect of anthropogenic activities (notably deforestation, logging and land conversion) on carbon stocks (Henry et al. 2009; Bryan et al, 2010), but only few documented studies (Losi et al., 2003; Meersmans et al., 2008; Attua, 2009) exist on identifying factors that are likely to influence the stock of SOC using multiple regression model.

The need to study factors influencing the stock of SOC has been acknowledged by scholars, for instance, Lal (2005) posits that understanding the mechanisms and factors of SOC dynamics in forest soils is important to identifying and enhancing natural sinks for $\mathrm{C}$ sequestration to mitigate the climate change challenges. In this study, the effects of a set of predictor variables (stem density, vegetation cover, aboveground biomass, soil moisture content, total nitrogen, cation exchange capacity and Av. P) on the stock of SOC (criterion variable) is investigated using stepwise multiple regression analysis. The essence however, is to identify main soil and vegetation variables that significantly influence the stock of SOC in order to suggest ways of maintaining the identified factors through sustainable agricultural and land management practices.

\section{Materials and Methods Study Area}

The study was carried out in Oban Group Forest in Akamkpa Local Government Area, Cross 
River State. Geographically, the area lies between longitude $8^{\circ} 060^{\prime}$ and $8^{\circ} 50^{\prime} \mathrm{E}$ and latitude $5^{\circ} 00^{\prime}$ and $5^{0} 57^{\prime} \mathrm{N}$. The climate is characterized by a double maxima rainfall beginning in the month of March to August, then August to October, reaching its peak in the month of July and September. The annual rainfall is about $2000-3000 \mathrm{~mm}$ with average temperature of about $27^{\circ} \mathrm{C}$, while relative humidity is about $80 \%$. The area is characterized by luxuriant evergreen forest vegetation with few patches of secondary forest which constitute the fallows. The rainforest consists of broad leaves species, amounting to $60-100$ species per sq $\mathrm{km}$ (Offiong, 2005). Many trees grow to the height of $30 \mathrm{~m}-60 \mathrm{~m}$ tall. A larger number of trees have large buttresses, smooth balks, columnar holes and thick woody climbers. Several species of birds, mammals, reptiles and insects are found in the area. The soils of the area are mainly loamy-sand and clay-loam (Offiong, 2005). The terrain is undulating with flood plains around the Ikpan River.

\section{Sampling procedure and analysis}

Systematic sampling method (line transect) was employed to collect soil and vegetation data by establishing plots across different generations of fallows. All plots were located on well-drained soils of gentle topography not exceeding 3 degrees. The areas of sampling have similar climate and parent material being granitic rock. The fallows comprised $1^{\text {st }}$ generation, $2^{\text {nd }}$ generation, $3^{\text {rd }}$ generation, $4^{\text {th }}$ generation and $5^{\text {th }}$ generation. In this regard, $1^{\text {st }}$ generation fallow refers to a piece of land that has been cultivated once in the past 70 years; $2^{\text {nd }}$ generation fallow is a piece of land that is cultivated twice in the past 70 years and so on. In each generation of fallow, two line transects of $120 \mathrm{~m}$ were established with interval of $5 \mathrm{~m}$ inbetween, out of which 12 plots of $20 \mathrm{~m} \times 20 \mathrm{~m}$ were laid. Out of the 12 plots, 6 were randomly selected. In all, 30 plots were selected. In each plot, all woody stems $\geq 0.15 \mathrm{~m}$ diameter at breast height (DBH) were identified, measured and counted regardless of tree or shrub species (Hall and Okali, 1979). The vegetation data determined include stem density, vegetation cover and aboveground biomass.

Data on vegetation cover was obtained using the line-intercept method (Jennings et al., 1999; Coulloudon et al., 1999), while data on tree girth was taken at $1.30 \mathrm{~m}$ DBH from the ground (Hall and Okali, 1979). In addition, aboveground biomass was estimated using the allometric formula given by FAO (1989) for tropical areas

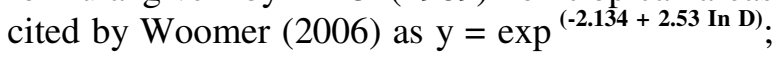
where $\mathrm{y}=$ aboveground biomass in kilogrammes; $\exp =2.71828$ and $\mathrm{D}$ is the measured tree girth in metres. In the same way, thirty (30) soil samples were collected using a soil auger at rooting depth of $30 \mathrm{~cm}$. The soils were stored in zip-loc bags and placed in a cooler to keep the samples at a moderate temperature. They were then taken to the laboratory for analysis. Organic carbon was determined by the Walkley-Black method (1943); total nitrogen by the Kjeldahl method (Bremner and Mulvaney, 1982), while available phosphorus was determined by the method of Bray and Kurtz (1945). The soils were leached with 1M neutral ammonium acetate to obtain leachates used to determine soil cation exchange capacity, while soil moisture content was determined using the gravimetric method.

\section{Data analysis}

Data obtained were analysed using stepwise multiple regression analysis with the aid of SPSS 17.0 software package. In searching for a statistical explanation of carbon stock in fallow soil, a correlation matrix (Pearson's correlation) was first applied to the datasets; this is required (Bryman \& Cramer, 1997; Kinnear and Gray, 1999) when sorting out suitable predictor variables for regression analysis as well as finding intercorrelated variables to be considered in the analysis. However, modeling was done using the stepwise method of regression analysis; this approach according to Attua (2009) is useful when trying to find the best subset of predictors.

\section{Results and Discussion}

The descriptive statistics of variables used as predictor variables of SOC across the generation of fallows are shown in table 1.

The zero-order correlation matrix in table 2 shows the Pearson's correlations between SOC and the predictor variables with significant $p$-values of 0.01 and 0.05 . It shows that TN and SMC had high positive correlations with SOC, while SMC had a high negative correlation with SOC. In addition, Av. P had a low positive and significant relationship with SOC. Thus, high positive correlation (0.80) was found between SOC and predictor variables $\mathrm{TN}$ and $\mathrm{VC}$, while high 
negative correlation $(0.84)$ existed between SOC and SMC. The lowest positive and significant correlation was found between SOC and variables Av. P, SD and AGB of $0.39,0.42$ and 0.63 respectively. A cursory look at the table further reveals that CEC had very low and negative associations with SOC and other predictor variables (table 2), as such was eliminated from the model.

The result of step-wise multiple regression analysis of the joint contribution $\left(\mathrm{R}^{2}\right)$ of predictor variables on the stock of SOC is shown in table 3. The result shows that out of the 6 predictor variables (TN, SMC, Av. P, VC, SD and ABG) simultaneously entered into the model, only 3 (TN, Av. $\mathrm{P}$ and VC) were significant in influencing the proportion of SOC. As such, three models explaining the stock of SOC were established. In the first model, vegetation cover (VC) was retained and significantly $(\mathrm{p}<0.01)$ contributed $78 \%$ to the stock of SOC (table 3). This is obvious as VC helps to reduce raindrop intensity and minimizes the loss of soil nutrient through runoff (Aweto \& Dikinya, 2003; Iwara, 2008). In addition, VC helps in SOC enrichment through the accumulation of biomass which in situ decomposes to form nutrient (Ross et al., 2002). The second model shows that vegetation cover (VC) and available phosphorus (Av. P) were retained and they significantly $(p<0.01)$ contributed $87 \%$ to the content of SOC (table 3). Av. P is an essential nutrient for plant growth, and is a primary fertilizer element; this element in the soil may have been enhanced due to the reduced frequency of disturbance (food crop cultivation), which probably results in the abundance of woody and herbaceous vegetation with high litter input.

In the third model, with the introduction of total nitrogen (TN), the stock of SOC in the soil significantly increased to $89 \%$. Indeed, the inclusion of $\mathrm{TN}$ in the model improved the accuracy of predicting SOC in the first and second models by $11 \%$ and $2 \%$ respectively. Total nitrogen is observed to improve soil quality which in the long-run encourages plant growth. The increase in plant growth results also in the amount of biomass (above-and below-ground) returned to the soil, which increases the stock of SOC (Ross et al., 2002). Thus, a significant portion of variability in SOC was explained by $\mathrm{VC}, \mathrm{Av} . \mathrm{P}$ and. TN (table 3). In a similar study, Attua (2009) found
$95 \%$ of the variability in SOC to be explained by CEC, TN and LA. This therefore reveals that the stock of SOC is determined by natural or anthropogenic (land management practices) factors. A further look at table 3 reveals that the residual error reduced greatly by 0.463 and 0.112 from the first to the third model probably because of the inclusion of Av. P and TN. The decreased in trend of residual error was also observed by Attua (2009). The results therefore indicate that the third model was most significant in predicting SOC, because it explained $89 \%$ variability in SOC $\left(\mathrm{R}^{2}=\right.$ 0.89). This means that the presence in large quantities of these variables (VC, Av. P and TN) will go a long-way in improving the stock of carbon in the soil. However, management of the variables identified in the full model (third) which perhaps are inextricable to the abundance of woody and herbaceous vegetation will not only increase the stock of SOC, but reduce its concentration in the atmosphere. This according to Aweto (1976: 1981) is because the rapid buildup of SOC and nutrients depends on the availability of woody perennials which produce a lot of litter and protect the soil against nutrient losses through leaching and rapid decomposition of litter.

\section{Conclusion/Recommendations}

The study reveals that vegetation cover, available phosphorus and total nitrogen explain significant portion in the variability of carbon in the soil. SOC is an essential component of the earth's ecosystem due to its importance in maintaining life-balance, as such, it stock in the soil needs to be sustained and enhanced. However, in order to sustain the amount of carbon in the soil, the identified ecological factors should be enhanced through the application of good forest and land management practices, such as creation of vegetal buffer zones around farmlands, zero-tillage practice, mulching, retaining of forest slash and crop residues, fertilizer application, elongation of fallow periods, and tree planting initiatives in degraded areas among others. Through these healthy practices, forest vegetation can be maintained; thereby increasing the $\mathrm{C}$ stock of forest soil by reducing direct loss to the atmosphere. An increase in the stock of SOC will positively impact on nutrient availability, improve soil structure (by holding soil particles together thereby improving water holding capacity, root 
growth, water infiltration), as well as act as a buffer for toxic substances (SOC lessen the effect of heavy metal by acting as a buffer).

\section{Acknowledgement}

The authors wish to thank Uguru Wisdom Ibor for his helpful comments.

\section{References}

Attua, E. M. (2009), Using Multiple Linear Regression Techniques to Quantify Carbon Stocks of Fallow Vegetation in the Tropics. West African Journal of Applied Ecology, 12: 1 - 7

Aweto, A. O. (1977), Soil Regeneration under Natural Fallows. Postgraduate/Staff Seminar, Dept. of Geography, University of Ibadan, Nigeria Aweto, A. O. (1981), Secondary Succession and Soil Fertility Restoration in South-Western Nigeria: Soil and Vegetation Interrelationships. $J$. Ecology, 69: 957-963

Aweto, A. O. and Dikinya, O. (2003), The Beneficial Effects of two Tree Species on Soil Properties in a Semi-Arid Savanna Rangeland in Botswana. Land Contamination \& Reclamation, 11 (3): $339-344$

Batjes, N. H. (1996), Total C and N in Soils of the World. Eur J Soil Sci., 47:151-163

Bray, R. H. and Kurtz, L.T. (1945), Determination of Total Organic and Available Forms of Phosphorus in Soils. Soil Sci., 59: 39-48

Bremner, J. M. and Mulvaney, C. S. (1982), Total nitrogen In: C.A. Black. (ed.) Methods of Soil Analysis, Part 2, Agronomy 9. American Society of Agronomy Inc. Madison, Wisconsin: pp.11491178

Bryan, J., Shearman, P., Ash, J. and Kirkpatrick, J. B. (2010), Estimating Rainforest Biomass Stocks and Carbon Loss from Deforestation and Degradation in Papua New Guinea 1972-2002: Best Estimates, Uncertainties and Research Needs. Journal of Environmental Management, 30: 1-7.

Bryman A. and Cramer D. (1997), Quantitative Data Analysis with SPSS for Windows. A Guide for Social Scientists. London: Routledge

Chandler, R. F. (1939), Cation Exchange Properties of Certain Forest Soils in the Adirondack Section. J. Agric. Res., 59, 491-505.

Chave, J., Andalo, C., Brown, S., Cairns, M. A., Chambers, J. Q., Eamus, E., Folster, H., Fromard, F., Higuchi, N., Kira, T., Lescure, J. P., Nelson, B. W., Ogawa, H., Puig, H., Riera, B. and Yamakura,
T. (2005), Tree Allometry and Improved Estimation of Carbon Stocks and Balance in Tropical Forests. Oecologia, 145: 87-99

Coulloudon, B., Eshelman, K., Gianola, J., Habich, N., Hughes, L., Johnson, C., Pellant, M., Podborny, P., Rasmussen, A., Robles, B., Shaver, P., Spehar, J. and Willoughby, J. (1999), Sampling Vegetation Attributes. Technical Reference 1734-4, U.S. Department of Agriculture, Natural Resource Conservation Service, Grazing Land Technology Institute

Dey, S. K. (2005), A Preliminary Estimation of Carbon Stock Sequestrated through Rubber (Hevea brasiliensis) Plantation in North Eastern Regional of India. Indian Forester, 131(11):1429-1435.

Dixon, R. K., Brown, S., Houghton, R.A., Solomon, A.M., Trexler, M.C. and Wisniewski, J. (1994), Carbon Pools and Fluxes of Global Forest Ecosystems. Science, 263: 185-190

Elliot, W. J. (2003), "Soil Erosion in Forest Ecosystems and Carbon Dynamics", in Kimble, J.M.; Heath, L.S.; Birdsey, R.A. and Lal, R. (Eds.), The Potential of US Forest Soils to Sequester Carbon and Mitigate the Greenhouse Effect. CRC Press, Boca Raton, FL, pp. 175-190.

Hairiah, K., Sitompul, S. M., van Noordwijk, M. and Palm, C. (2001), Methods for Sampling Carbon Stocks Above and Below Ground. http://www.icraf.cgiar.org/sea

Hall, J. B. and Okali, D. U. U. (1979), A Structural and Floristic Analysis of Woody Fallow Vegetation near Ibadan, Nigeria. Journal of Ecology, 67: 321 - 346

Henry, M., Gineste, M., Martel, S., Asante, W., Adu-Bredu, S., and Saint-Andre, L. (2009), Impact of Forest Degradation caused by Selective Logging on Carbon Stocks in a Wet Evergreen Forest of Ghana. Paper Presented at the XIII World Forestry Congress Buenos Aires, Argentina, 18 - 23 October

Hoover, C. M. (2003), "Soil Carbon Sequestration and Forest Management: Challenges and Opportunities", in: Kimble, J.M., Heath, L.S., Birdsey, R.A. and Lal, R. (Eds.), The Potential of U.S. Forest Soils to Sequester Carbon and Mitigate the Greenhouse Effect.CRC Press, Boca Raton, FL, pp. 211-238.

Iwara, A. I. (2008), The Concept of Tree Influence Cycle. Seminar Presentation (GEO 713), Dept. of Geography, University of Ibadan, Nigeria 
Jennings, S. B., Brown, N. D. and Sheil, D. (1999), Assessing Forest Canopies and Understorey Illumination: Canopy Closure, Canopy Cover and other Measures. Forestry 72(1): 59-74

Jina, B. S., Sah, P.; Bhatt, M. D. and Rawat, Y. S. (2008), Estimating Carbon Sequestration Rates and Total Carbon Stockpile in Degraded and NonDegraded Sites of Oak and Pine Forest of Kumaun Central Himalaya. ECOPRINT, 15: 75-81

Kinnear P. R. and Gray C. D. (1999), SPSS for Windows Made Simple, third edition. United Kingdom: Psychology Press Ltd

Lal, R. (2005), Forest Soils and Carbon Sequestration. Forest Ecology and Management, 220: $242-258$

Larionova, A. A., Rozanova, L. N., Evdokimov, I. V. and Ermolaev, A. M. (2002), Carbon Budget in Natural and Anthropogenic Forest- Steppe Ecosystems. Pochvovedenie, 2:177-185.

Losi, C. J., Siccamaa, T. G., Conditb, R. and Morales, J. E. (2003), Analysis of Alternative Methods for Estimating Carbon Stock in Young Tropical Plantations. Forest Ecology and Management, 184: 355-368

Lu, D., Mausel, P., Brondizio, E. and Moran, E. (2002), Aboveground Biomass Estimation of Successional and Mature Forest using TM Images in the Amazon Basin. Symposium on Geospatial Theory, Processing and Applications, Ottawa, Canada

Meersmans, J., De Ridder, F., Canters, F., De Baets, S. and Van Molle, M. (2008), A Multiple Regression Approach to Assess the Spatial Distribution of Soil Organic Carbon (SOC) at the Regional Scale (Flanders, Belgium). Geoderma, $143(1-2): 1-13$

Offiong, R. A. (2005), Flora Biodiversity of the Kwa Falls River Valley: A Case Study of Akamkpa Local Government Area, Cross River State,
Nigeria. Unpublished M.Sc Thesis, University of Calabar.

Prichard, S. J., Peterson, D. L. and Hammer, R. D. (2000), Carbon Distribution in Sub-alpine Forests and Meadows of the Olympic Mountain, Washington. Soil Sci. Soc. Am. J., 64, 1834- 1845

Ross, D. J., Tate, K. R., Scott, N.A., Wilde, R.H., Rodda, N. J. and Townsend, J.A. (2002), Afforestation of Pastures with Pinus radiata influences Soil Carbon and Nitrogen Pools and Mineralization and Microbial Properties. Aust. J. Soil Res., 40, 1303-1318

Sheikh, M. A., Kumar, M. and Bussmann, R. W. (2009), Subtropical and Broadleaf Temperate Forests in Garhwal Himalaya. Carbon Balance and Management, 4:1 - 6

Thornley, J. H. M. and Cannell, M. G. R. (2000), Managing Forests for Wood Yield and Carbon Storage: A Theoretical Study. Tree Phys., 20, 477484

Walkley, A. and Black, I.A. (1934), An examination of the Detjareff Method for Determining Soil Organic Matter and a Proposed Modification to the Chromic Acid Titration Method. Soil Science, 37, 29-38

Watson, R.T., Noble, I. R., Bolin, B., Ravindranathan, N. H. and Verardo, D. J. (eds.) (2000), Land Use, Land Use Change and Forestry. Special Report of the Intergovernmental Panel on Climate Change. U.K.: Cambridge University Press, Cambridge.

Wilcox, C. S., Dominguez, J., Parmelee, R.W. and McCartney, D.A. (2002), Soil Carbon and Nitrogen Dynamics in Lumbricus terrestris. L. middens in Four Arable, a Pasture, and a Forest Ecosystems. Biol. Fertil. Soils, 36, 26-34 Woomer, P. L. (2006), Estimating Carbon Stocks in Smallhold Agricultural Systems. http://www.formatkenya.org/ormbooks/Chapters/c hapter7.htm 
Table 1 Descriptive statistics of the predictor and criterion variables

\begin{tabular}{lccccc}
\hline Variables & Units & Minimum & Maximum & Mean & Std. Deviation \\
\hline SOC & $\%$ & 0.20 & 1.28 & 0.96 & 0.38 \\
TN & $\mathrm{Kg}$ & 0.21 & 0.34 & 0.27 & 0.03 \\
CEC & Meq $/ 100 \mathrm{~g}$ & 4.00 & 9.00 & 4.56 & 0.85 \\
SMC & $\%$ & 27.6 & 33.7 & 29.99 & 2.34 \\
Av. P & $\mathrm{mg} / \mathrm{kg}^{-1}$ & 1.00 & 101.29 & 25.73 & 38.76 \\
VC & $\%$ & 48.7 & 80.6 & 67.60 & 9.77 \\
SD & Numerical & 17 & 33 & 23.77 & 4.73 \\
AGB & $\mathrm{Kg}$ & 1.08 & 4.57 & 2.50 & 1.10 \\
\hline
\end{tabular}

$\mathrm{SOC}=$ soil organic carbon; $\mathrm{TN}=$ total nitrogen $\mathrm{CEC}=$ cation exchange capacity $; \mathrm{SMC}=$ soil moisture content; Av. $\mathrm{P}=$ available phosphorus, $\mathrm{VC}=$ vegetation cover; $\mathrm{SD}=$ stem density; $\mathrm{AGB}=$ aboveground biomass

Table 2 Zero-order correlation matrix of the variables

\begin{tabular}{lcccccccc}
\hline & SOC & TN & CEC & SMC & Av. P & VC & SD & AGB \\
\hline SOC & 1 & & & & & & & \\
TN & $0.83^{* *}$ & 1 & & & & & & \\
CEC & -0.05 & -0.16 & 1 & & & & & \\
SMC & $-0.84^{* *}$ & $-0.83^{* *}$ & $-0 . .06$ & 1 & & & & \\
Av. P & $0.39^{*}$ & $0.69^{* *}$ & $-0.36^{*}$ & $-0.50^{*}$ & 1 & & & \\
VC & $0.89^{* *}$ & $0.90^{* *}$ & -0.13 & $-0.90^{* *}$ & $0.68^{* *}$ & 1 & & \\
SD & $0.42^{*}$ & $0.64^{* *}$ & -0.07 & $-0.66^{* *}$ & $0.72^{* *}$ & $0.67 * *$ & 1 & \\
AGB & $0.63^{* *}$ & $0.85^{* *}$ & -0.33 & $-0.70^{* *}$ & $0.93^{* *}$ & $0.85^{* *}$ & $0.78^{* *}$ & 1 \\
\hline
\end{tabular}

*. Correlation is significant at the 0.05 level (2-tailed)

**. Correlation is significant at the 0.01 level (2-tailed)

Table 3 Result of step-wise multiple regression

\begin{tabular}{|l|c|c|c|c|}
\hline Predictor variables & $\mathrm{R}$ & $\mathrm{R}^{2}$ & F-values & Regression equations \\
\hline VC & 0.89 & 0.78 & $101.531^{*}$ & $\mathrm{Y}=-1.41+0.04 \mathrm{VC}$ \\
\hline VC + Av. P & 0.93 & 0.87 & $87.156^{*}$ & $\mathrm{Y}=-2.01+0.05 \mathrm{VC}-0.01 \mathrm{Av} . \mathrm{P}$ \\
\hline VC + Av. P + TN & 0.95 & 0.89 & $71.679^{*}$ & $\mathrm{Y}=-2.35+0.03-0.01 \mathrm{Av} . \mathrm{P}+4.28 \mathrm{TN}$ \\
\hline
\end{tabular}

*Significant at $1 \%$ alpha level 